\title{
POSSIBLE CHANGES IN THE HOLOCENE WIND PATTERN RECORDED ON SOUTHEASTERN BRAZILIAN COAST
}

\section{L.Martin ${ }^{1}$}

J.M.Flexor ${ }^{2}$

K.Suguio ${ }^{3}$

\section{ABSTRACT}

The Pacific oceanographic phenomenon "EL Niño" is responsible, during some months, for very significant atmospheric circulation disturbances in the coasts of southern Equador and Northern Peru. Consequently, derangements of some natural mechanisms, directly or indirectly related to wind patterns, are produced along northeastern, southeastern or southern coasts of Brazil. During Holocene, "El Niño" - like disturbances with longer duration (some tens or even hundreds of years), have been recorded in some places of this country.

\section{INTRODUCTION}

During 1983, an important "El Niño" phenomenon occurred along the mentioned South American coasts. This oceanographic disturbance induced worldwide changes in atmospheric circulation patterns. Particularly in Brazil, changes in the wind and rainfall regimes were stressed by the presence of warm waters along Peruvian and Equatorial coasts (KOUSKY et al., 1984). Then, the Cabo Frio (State of Rio de Janeiro) local upwelling, induced by the northeastern trade winds, was enhanced with changes in wave regimes and consequent direction of longshore drift of sands.

\footnotetext{
1ORSTOM/ON-CNPq, 20.921 - Rio de Janeiro, Brazil.

${ }^{2}$ ON-CNPq/Dpto. de Geofísica, 20.921 - Rio de Janeiro, Brazil.

${ }^{3}$ Instituto de Geociências/USP, 05508 - São Paulo, Brazil.
} 
On the other hand, indirect evidence of changes in upwelling intensities, during the last 5,000 years, are recorded in carbonate deposits of a very small hypersaline lake in the area. Similarly, changes in direction of longshore transportation of sands have been recognized in Doce river mouth (State of Esp(rito Santo) coastal plain. They could be explained only by inversion in dominant wave direction, which is a consequence of changes in atmospheric circulation. It is possible to visualize, in both cases, an "El Niño"- Ilke situation during the last 5,000 years, with some tens or hundreds of years of duration and not of some months.

Some information from the Pacific ocean side seems to be in favour of this hypothesis. The Santa Helena cape, at Southern Equador, is the limit between the Humboldt current cold waters and the tropical warm waters. During normal situation, at the south of cape with cold waters, there is an arid climate, while at the north, there are mangrove swamps. During "El Niño" period, southern portion of this cape is invaded by warm waters with abnormally high rainfalls. This hypothesis seems to be reinforced by archeological researches done by BOGIN (1982), which indicated climatic alternations characterized by dry and wet periods, on a secular time scale, in southern portion of Santa Helena cape on the Equador coast.

Similarly, during normal situation, the rivers in Northern Peru are characterized by small quantities of coarser sediments. However, series of discontinuous beach ridges, at neighbors of their mouths, according to ORTUEB et al. (1989), have been formed during high transportation rate like that produced by "E Niño" phenomenon. Considering that these beach ridges are very well developed, it seems to be more reasonable to think that these rainy episodes could have a duration of, at least, several years and not some months. Finally, it seems to be logical to think that the inhabitation of the Polynesian islands occurred westeastwardly and not against the eastwestwardly blowing trade winds. This is the reason why an american anthropologist (in HISARD, 1989) emitted a hypothesis that the Polynesian islands inhabitation occurred during "E Niño" phenomenon. However, some months of isolated "El Niño" period, in general characterized by a bad weather, could be an obstacle for migration. On the contrary, if a longer "El Niño"like phenomenon occurred, with some periods of stability in meteorological and hydrological conditions, this migration could have been favoured.

\section{THE PACIFIC OCEAN AND "EL NIÑO" PHENOMENON}

During normal situation in Southern Pacific, an anticyclone is centered over the Easter island. The western Pacific is dominated by a low pressure zone which guides the trade winds eastwards along th Equator. These westwardly blowing winds exert a tension on the ocean surface with a consequent accumulation of warm waters at the west and an upwelling of cold waters along the Pacific coast of South America. Occasionally, it occurs an inversion of this pressure gradient with weakling or inversion of wind 
direction (Austral oscillation). This phenomenon is followed, in the Eastern Pacific, by an increase of the ocean temperature, not only on the equatorial region but on both sides of the Equator. This occasional appearance of warm waters along the coast of Southern Equador and Northern Peru, which occurs generally in December, is known as "El Niño" phenomenon.

\section{THE ATMOSPHERIC CIRCULATION IN SOUTH AMERICA}

The normal condition of air mass circulation over South America, during the austral autumn and winter, is characterized by the passage, within midlle and upper troposphere, of a succession of meridian waves and, on the surface, by corresponding frontal systems. In the ocean, the frontal systems are accompanied by winds and waves which come from the southern sector. This is more frequent during austral autumn and winter and its effects are felt as far as latitude $12^{\circ} \mathrm{S}$ (Fig. 1A). In periods of strong " $\mathrm{El}$ Niño" activity, the polar advections are blocked by a powerful and permanent subtropical jetty current, which extends from the Peruvian coast (Pacific ocean) towards the Southern Brazil crossing Northern Chile and Argentina (Fig. 1B). Due to this blockage, the frontal zones and the associated southern sector waves did not ascend northwards causing the existence of two contrasting zones in Brazil: one marked by catastrophic inundations and another by severe dryness.

\section{CONSEQUENCE OF "EL NIÑO" PHENOMENON ON THE COAST OF SOUTHEASTERN BRAZIL}

Enhancement or annihilation of Cabo Frio (State of Rio de Janeiro) upwelling - the designation "frio" (cold), which was applied to this cape on the Brazilian coast by Portuguese navigators in the $16^{\text {th }}$ century, situated $110 \mathrm{~km}$ eastwards of the city of Rio de Janeiro (Fig. 2) - already testifies to the fact that there is a local thermal anomally here.

AШARD (1955) was the first author to recognize a correlation between wind direction and changes in surface water temperatures at Cabo Frio. Temperature is a minimum when winds come from the NE and increases when the winds come from the SSE. During spring and summer, the dominant winds related to trade winds come from the NE. In autumn and winter, the northeastern wind regime is disturbed by the invasion of polar air masses accompanied by winds from the southern sector. During austral spring and summer the mean temperature of the waters in the Cabo Frio region is cold, with a possible increase in temperature during periods of austral autumn and winter with actuation of the southern sector winds (Fig. 3A). MOREIRA DA SILVA (1973) demonstrated that the upwelling occurs in two phases: (a) from September to April, distancing oceanward of the Brazilian current allows the South Atlantic Central 


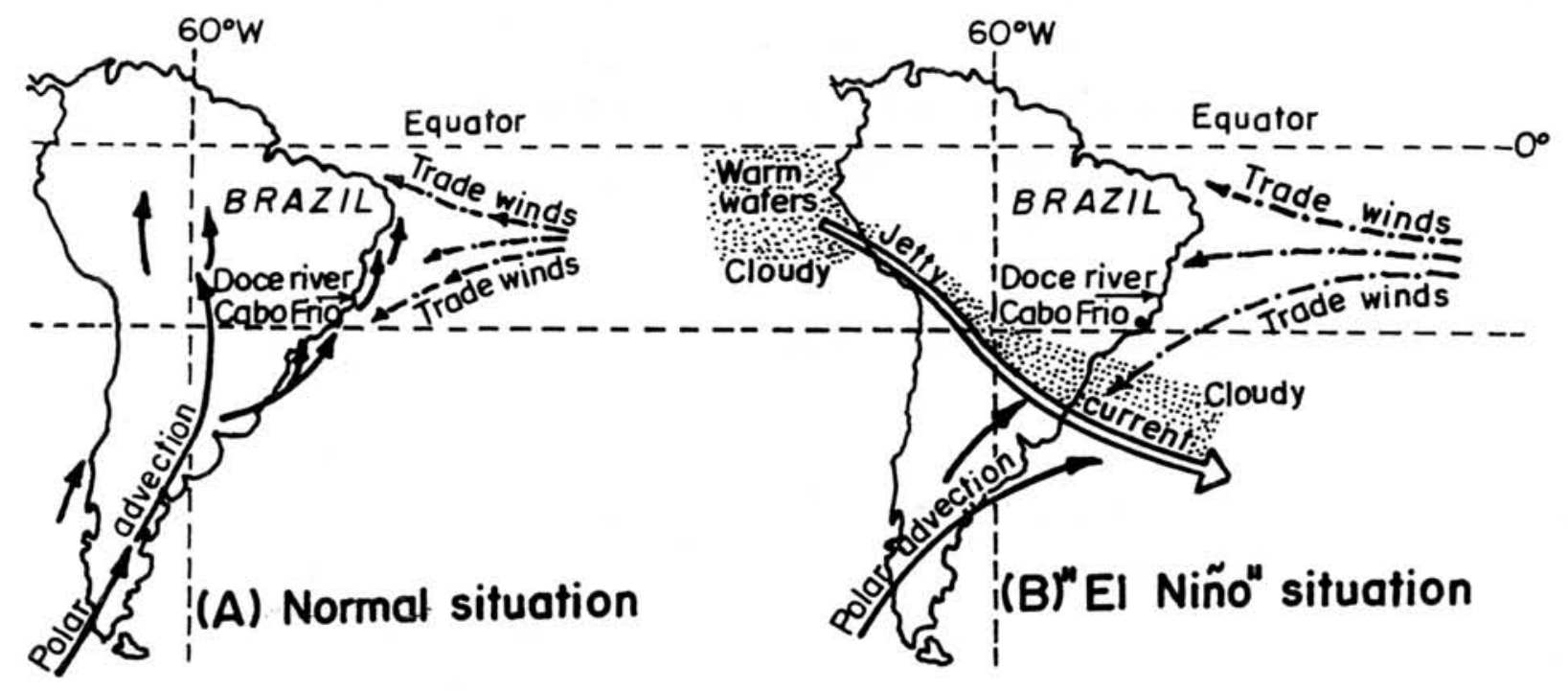

Figure 1 - Schematic trajectories of polar advections and trade winds, which are the generators of two wave systems active along central portion of the Brazilian coast.

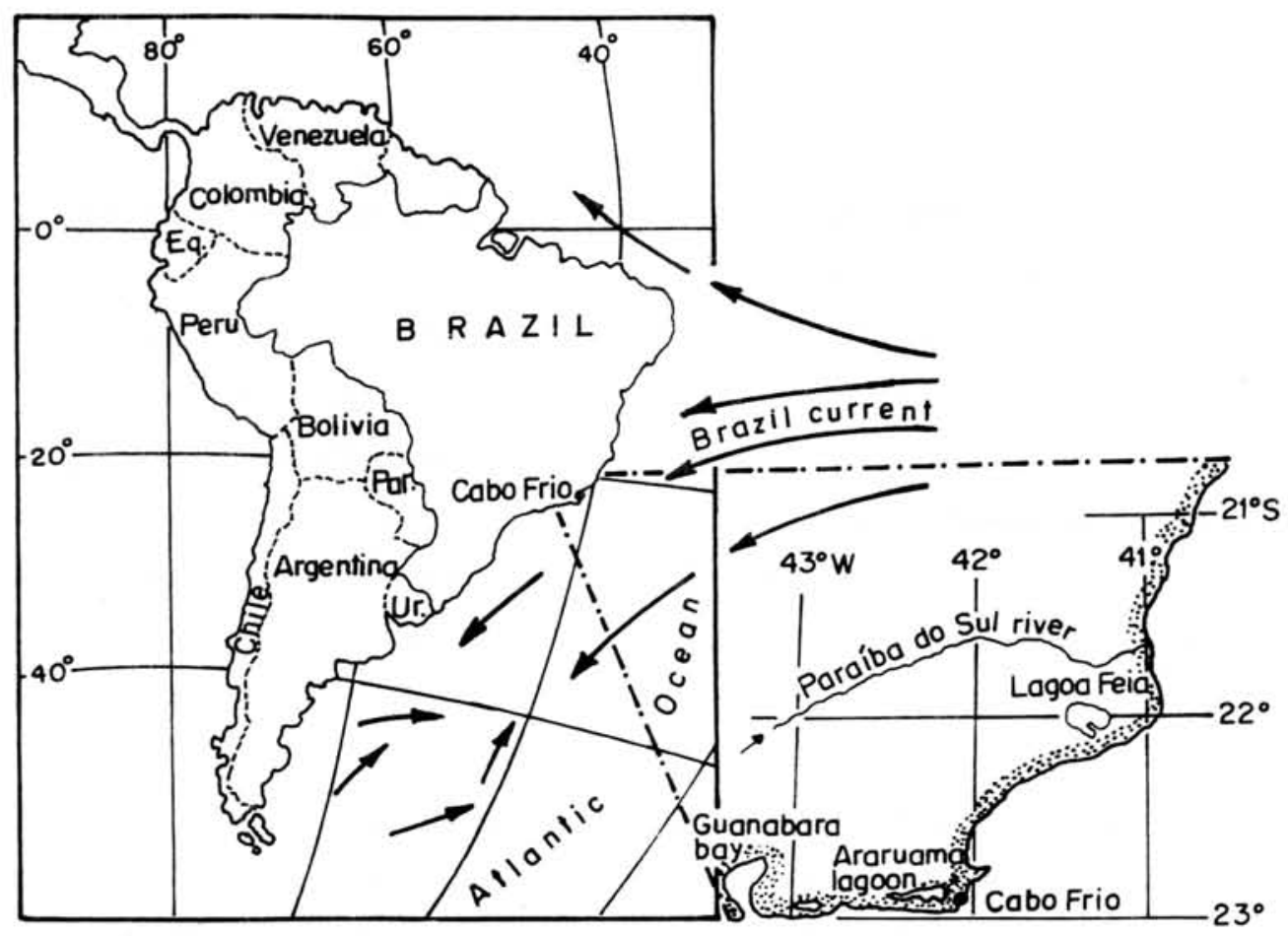

Figure 2 - Location map of Cabo Frio region, showing the position of the Brazil current and the abrupt change in coastline direction along the State of Rio de Janeiro. 
Waters to ascend on to the continental slope occupying the bottom of the continental shelf; (b) under influence of the northeastern winds, the cold waters ascend to the ocean surface. On the other hand, the winds from the southern sector, related to the passage of cold fronts, produce the retention of warmer coastal waters and, consequently, the submersion of cold waters.

The upwelling in the Cabo Frio region is related to three principal factors: (a) local topography (an abrupt change of coastline direction from the NE-SW to the E-W), (b) position of the axis of the Brazil current (Fig. 2), and (c) wind regimes. The first two factors, even so essential for location of phenomenon in this area, are not active over the intermittent upwelling of cold waters up to the surface, because only the winds supply with the motive power.

In 1983, the year of the important "El Niño" phenomenom along the Peru and Equador coasts, the surface ocean waters near Cabo Frio were abnormally cold (Fig. 3D). This situation is perfectly understandable, considering that after the blockage of cold fronts in Southern Brazil, as a consequence of the "El Niño" phenomenom the southern sector winds did not reach as far as the Cabo Frio region and the northeastern winds became very effective.

In 1972, which also corresponds to an "El Niño" year, it was possible to observe from March to September the presence of several periods of cold water (Fig. 3B), which can be considered as a normal year.

In 1976, which also corresponds to an "El Niño" year, it was possible to find an inverse situation: from March $15^{\text {th }}$ to July $15^{\text {th }}$ the surface ocean waters were permanently warm in the Cabo Frio region (Fig. $3 \mathrm{C}$ ), indicating that there were no winds from the NE during this period. As the "El Niño" was weaker than in 1983, it was possible that the zone of blockage was situated more northwards and that the Cabo Frio region was free from northeastern winds.

Thus, it appears that a relationship exists between the intensification or disappearance of upwelling in Cabo Frio and the occasional presence of warmer waters along the Equador and Peruvian coasts. According to the intensity of the "El Niño" phenomenon, the warm waters reach more-or-less southwards along the South American Pacific coast, modifying the position of the jetty current which diagonally crosses this continent. The presence or absence of northeastern winds, which originate the Cabo Frio upwelling, will depend upon the position of this jetty current. Depending upon the situation, there will either exist reinforcement or disappearance of upwelling.

Disturbance of longshore transportation along the Armação beach (Salvador, State of Bahia), when the wave fronts reach obliquely a coastline, longshore currents are originated, which promote a lateral transportation of sediments in sandy shorelines. The direction of this transportation is a function of wave fronts orientation. In central portion of the Brazilian coastline, there exists two types of waves. The first one comes from the NE and is related to trade winds, and the second one comes from the southern sector, being generated by penetration of polar air masses over the South Americam continent (Fig. 1). 


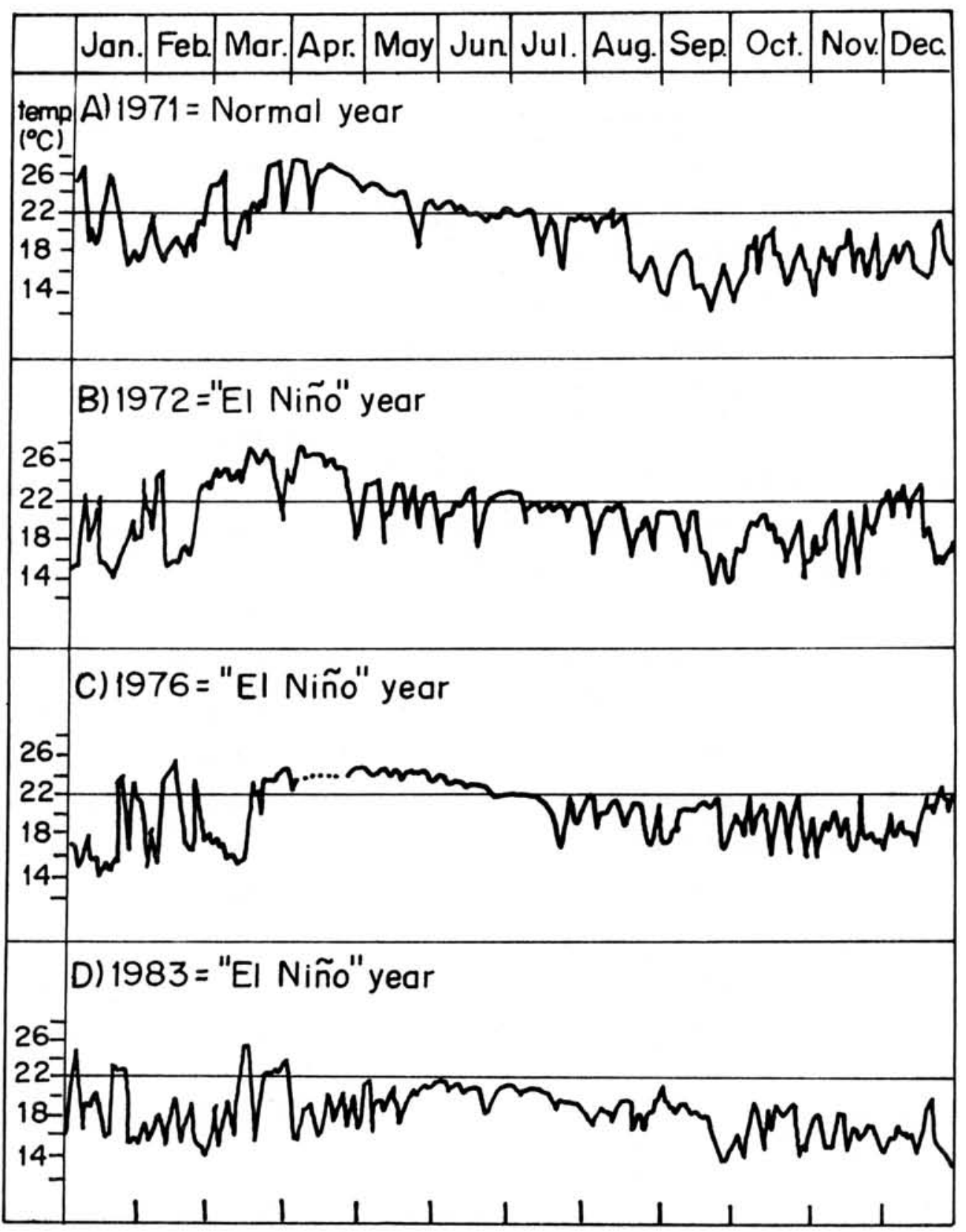

Figure 3 - Comparison between surface water temperature at Cabo Frio during normal and "曰 Niño" years. 
Armação beach is an about $3 \mathrm{~km}$-long bight limited between two rocky headlands (Fig. 4). FERREIRA DE FARIAS et al.(1985) demonstrated that, along this beach, there is a cyclic inversion in transportation of sands, noticeable from erosion in one extremity and deposition in other. Normally, in spring and summer, there is an erosion at the $\mathrm{N}$ and a deposition in the $\mathrm{S}$, as a consequence of the northeastern waves. On the other hand, in autumn and winter, this area is submitted to southeastern waves producing an opposite situation. In austral autumn and winter of 1983, the erosional phase of the southern extremity and the corresponding depositional phase at the northern extremity remained unchanged during more than 6 months, although in normal situation the passage of the first cold fronts produces the same consequence in less than one month. This is explained by an abnormally low frequency of the southern sector waves as a result of cold fronts blockage. However, there is a southnorthward transportation, much slower than in normal situation, related to the southeastern waves due to a deviation of trade winds.

\section{RECORDS OF "EL NIÑO" - LKE CONDITIONS IN THE HOLOCENE}

Variations in Cabo Frio upwelling intensity, in the Holocene, recorded in carbonate deposits of a hypersaline lagoon - the intermittent presence of cold waters in the Cabo Frio region provokes a significant decrease in precipitation, giving rise to a local microclimate $(750 \mathrm{~mm} / \mathrm{year}$ at the Arraial do Cabo Station, while the annual mean pluviosity in Marica, situated less than $100 \mathrm{~km}$ SW of Cabo Frio, is about $1,400 \mathrm{~mm} /$ year).

The coast of the State of Rio de Janeiro between Niterói and Cabo Frio is characterized by occurrence of two lagoonal systems. The inner one, formed by larger lagoons (Maricá, Guarapina, Jacone, Saquarema and Araruama), is separated from the ocean by beach ridges. Between them there is a lowland parallel to the present strandline which was occupied, during a sea-level higher than today, by another lagoonal systems partially connected with the first system. Presently, some sectors of the second lagoonal system were desiccated, however the depression between Saquarema and Cabo Frio is occupied by a chaplet of smaller lagoons (Fig. 5).

Lagoa Vermelha, about $4 \mathrm{~km}$ - long, 0.3 to $0.8 \mathrm{~km}$ - wide and less than $1.5 \mathrm{~m}$ - deep, is one of them which was studied in more detail. It is presently isolated within sandy deposits and, as there is no subaerial source of freshwater flowing into this lake, it does not receive any terrigenous supply probably being nourished by subterraneous percolation from the Araruama lagoon. As a consequence of the semiarid climate generated by the Cabo Frio upwelling, Araruama lagoon is hypersaline (salinity $=58^{\circ} / 00$ ). Lagoa Vermelha is also hypersaline but, due to its small size and shallowness, this property is very changeable as a function of precipitations.

A short core sample (about $1 \mathrm{~m}$ long) from this lake was studied from a geochemical and 


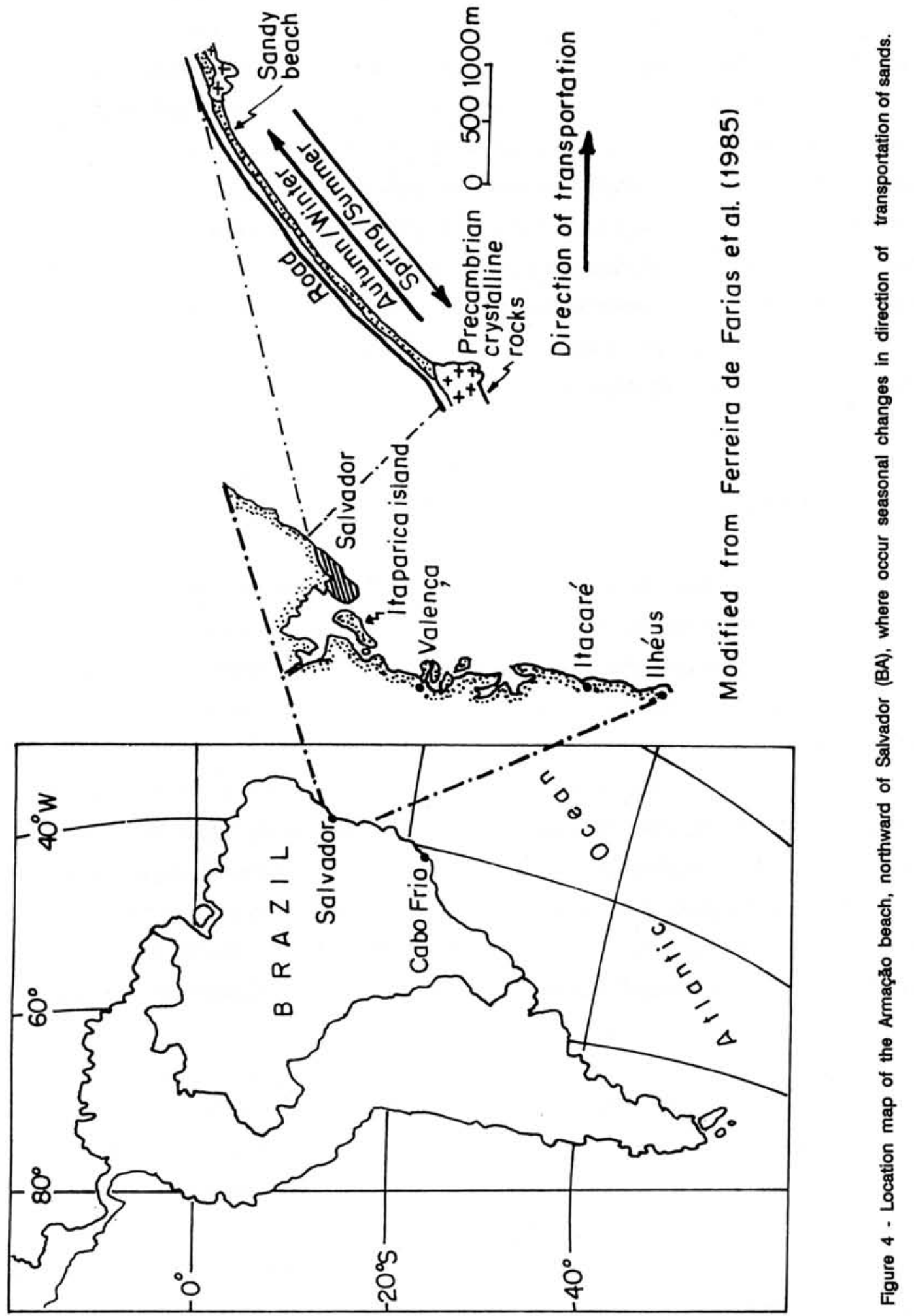




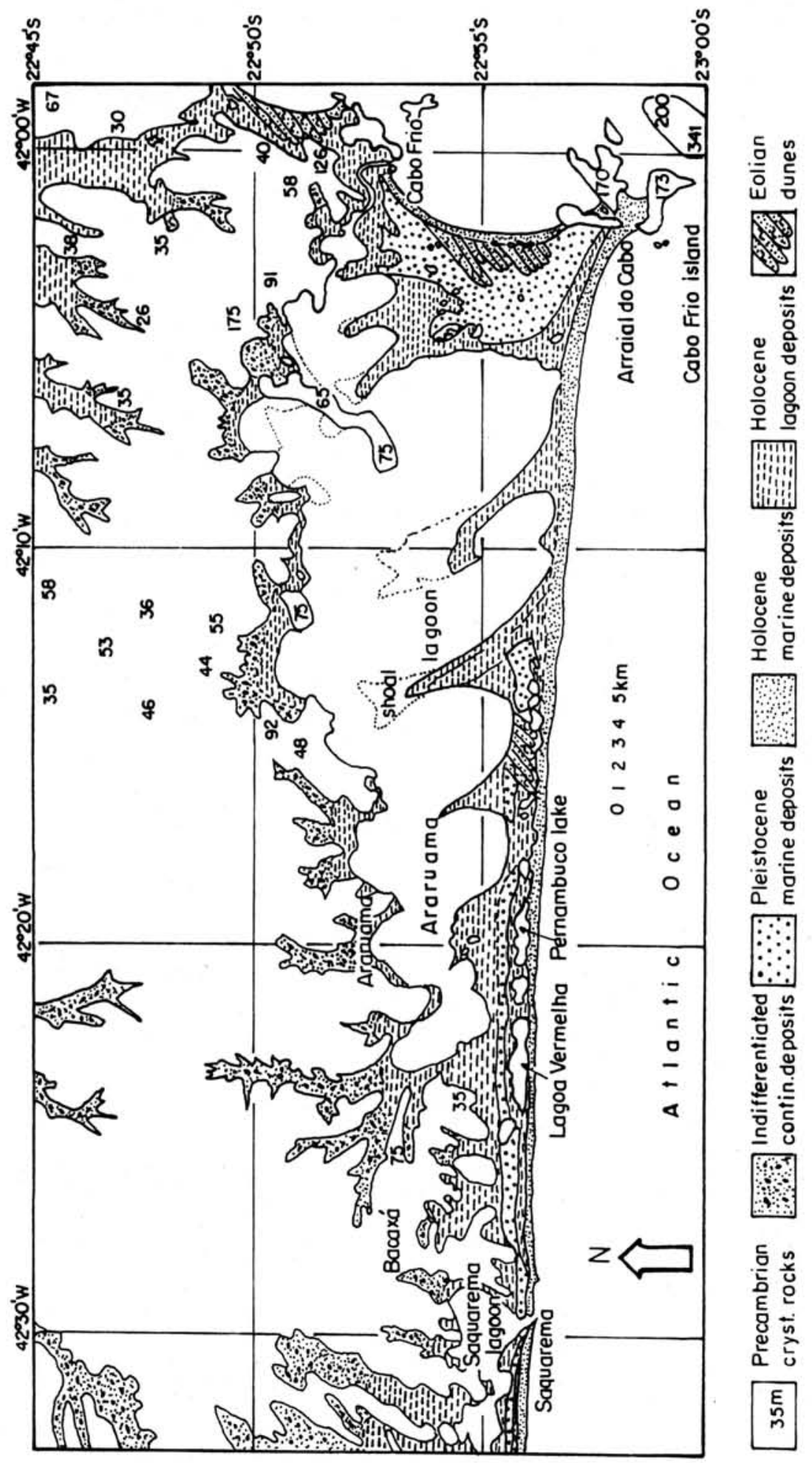

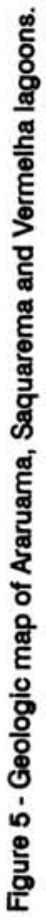


mineralogical viewpoint by SANTELU (1988), (Fig. 6). After its isolation, the sediments of the Lagoa Vermelha are essentially composed of carbonates and organic matter. The carbonates form 46 to $96 \%$ of the sediments. $X$ ray diffraction analyses have shown that the carbonates are composed of magnesian calcite, dolomite and aragonite. From the combined analytical data, it is possible to recognize two different parts. Considering this preliminary information, it is apparent that the carbonates found in this core sample were precipitated in two different environments. During sedimentation of the lower portion of the core, the environment was very rich in microalgae, cyanobacteria and photosynthetic bacteria and that there were very few organisms with carbonate tests $\left(\delta^{13} C_{P D B}\right.$ values between -10 and $-11^{\circ} \%$ ). This environment was clearly more saline which is indicated by $\delta^{18} \mathrm{O}_{\mathrm{PDB}}$ values higher in lower than in the upper portion. In some places, in the lower portion of the core the degradation of algal organic matter, due to a suitable $\mathrm{Mg}$ source, associated with strong evaporation, provoked the precipitation of dolomite. On the contrary, in the upper portion, the environment was characterized by a clearly lower salinity and great abundance of organisms with carbonate tests. The transition from an environment which was very rich in algae to one very rich in carbonate tests; associated with a decrease in salinity, propitiated the precipitation of aragonite. The surface layer, which is very fluid and characterizes present conditions, was not analysed but the presence of dolomite at the top the core and the great abundance of algae, associated with the absence of living molluscs suggests that, presently, the environment could be similar to which occurred during the deposition of the lower portion of this core. In some places, $\delta^{18} \mathrm{O}_{\mathrm{PDB}}$ variation curve for the upper portion, exhibits three or four small changes which were disregarded. Apparently, it is necessary to make more samplings and to analyse not systematically but according to the lithological changes.

Since Lagoa Vermelha is completely closed, the recorded salinity variations could be related to changes in the precipltation/evaporation ratio. This fact was ratified by analyses of ${ }^{2} \mathrm{H}$ (deuterium) an ${ }^{18} \mathrm{O}$ in waters of Lagoa Vermelha and the ocean; which showed a linear enrichment of ${ }^{2} \mathrm{H}$ in relation to ${ }^{18} \mathrm{O}$, indicating that evaporation was the most important mechanism controlling the hydraulic budget of the lake. These changes in the precipitation/evaporation ratio are necessarily related to modifications of the regional microclimate and thus to changes in the cabo Frio upwelling intensity. The decrease or disappearance of upwelling will induce an increase in precipitation and a decrease in evaporation. On the contrary, a reinforcement will provoke a decrease in precipitation and an increase in evaporation. Unfortunately, at present there are no dates available, to establish the chronology of events. As the studied core did not penetrate all the carbonate sequence, it is possible that other oscillations may be present within deeper sediments.

Records of ten phases of inversion in directions of dominant waves during the last 5,000 years recognized in the Doce river coastal plain - during the last 5,000 years, the central portion of the Brazilian coast was in general submitted to relative sea-level drop of about 4-5 m (SUGUIO et al., 1985 and MARTIN et al., 1987). On sandy shorelines a relative sea-level drop provokes an important sediment supply 

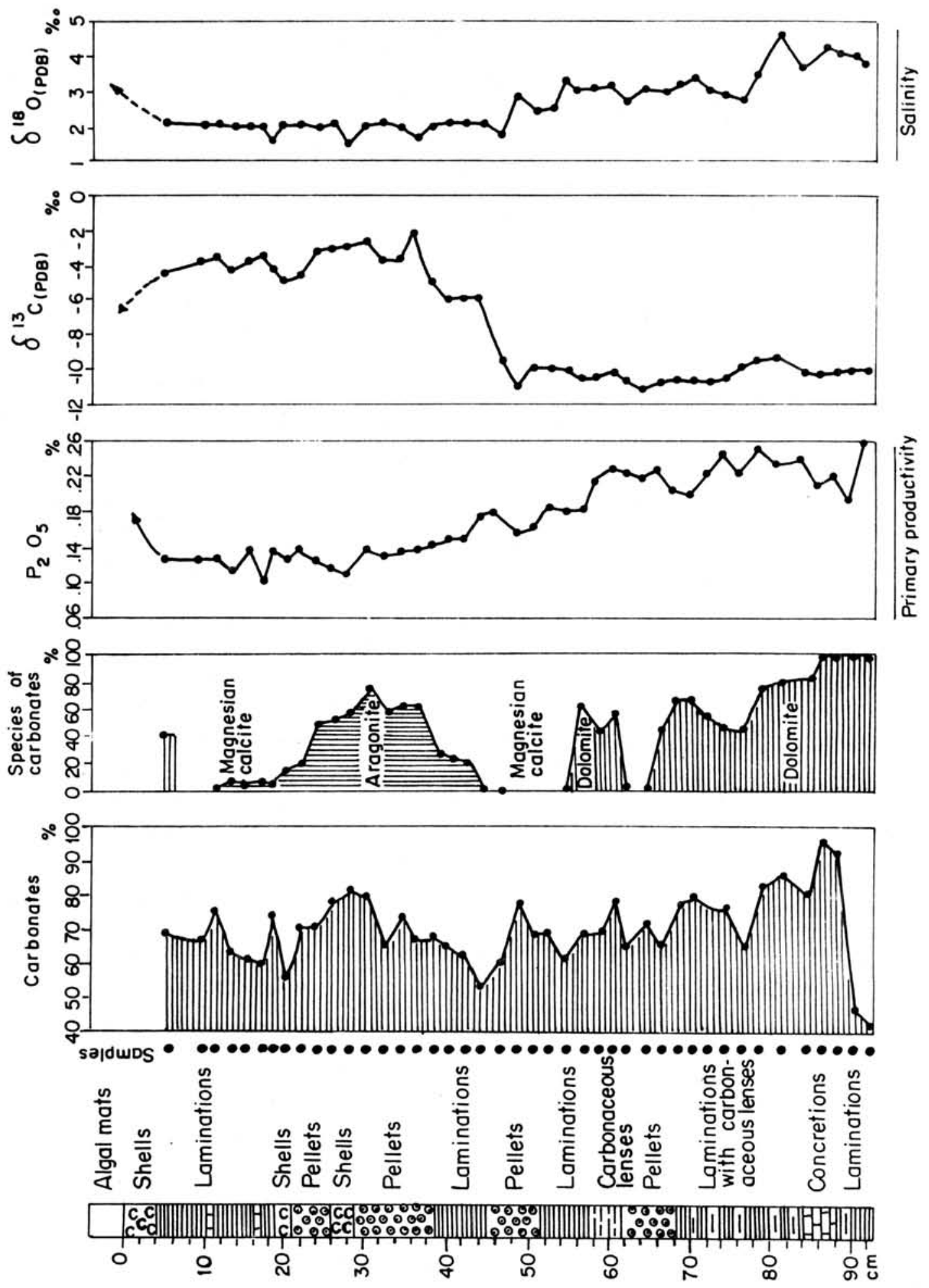
from the inner shelf toward the beach, together with possible river sources (MARTIN et al., 1987). These sands are frequently transported by littoral drift until they are impeded by an obstacle and their accumulation by horizontal piling results in beach ridges. A detailed study of their geometry allowed us to reconstruct the directions of transportation during their sedimentation. In some places, as the direction of transportation depends of the quadrant in which the wave fronts reach the shoreline, then it is clear that the knowledge, for a given time interval, of this direction, allow us to reconstruct the dominant wave patterns during this period.

In this part of the Brazilian coast there are presently two types of waves. The first type is most frequent and comes from NE quadrant, being derived from trade winds. The second type comes from S-SE quadrant, being related to the penetration of cold polar air masses into the South American continent. It is essential to emphasize that the latter, which are stronger than the former, play an important role in the littoral transportation of sands. Moreover, a few days or even hours of strong waves from the southern sector, related to the transit of cold polar fronts, is much more significant factor in sediment transportation than several months of weak waves from the northeastern sector.

Presently, the dominant littoral drift in the São Francisco river mouth area $\left(10^{\circ} \mathrm{S}\right)$, practically does not attained by the southeastern waves, is from $\mathrm{N}$ to $\mathrm{S}$. On the contrary, the areas of the Doce river mouth $\left(19^{\circ} \mathrm{S}\right)$ and the Parafba do Sul river mouth $\left(22^{\circ} \mathrm{S}\right)$, the dominant littoral drift is from $\mathrm{S}$ to $\mathrm{N}$, though they are also submitted to the northeastern waves. It has been possible to demonstrate that the littoral drift in the São Francisco river mouth area, during the last 5,000 years, occurred from $N$ to $S$ (DOMINGUEZ et al., 1983), and that the average direction in the Parafba do Sul river mouth area was from S to N. However, in the Doce river mouth area, the littoral drift changed about 10 times during the last 5,000 years (Fig. 7). Between 0 and 2,500 years B.P., the littoral transportation, which was in general from $S$ to $N$, was submitted to 3 inversions from $N$ to $S$. Between 2,500 and 4,100 years B.P., the direction of transportation was constant from $\mathrm{S}$ to $\mathrm{N}$, although two relative sea-level oscillations occurred during this period and evidence of inversions may have been destroyed. Between 4,100 and 5,100 years B.P., 7 inversions of the direction of transportation from $\mathrm{N}$ to $\mathrm{S}$ were recognized.

Those two different directions of littoral drift related to dominant waves, which have been recorded within beach ridges of Doce river coastal plain, could be explained by successive actuation of two systems of atmospheric circulation. When dominant waves came from the southern sector, the atmospheric circulation could be equivalent to that existing today, which is characterized by northward ascent of polar air masses (Fig. 1A). On the contrary, when the dominant waves came from the northern sector, the southern sector waves did not ascend the Doce river mouth, due to this blockage, as during "El Niño" periods (Fig. 1B). 

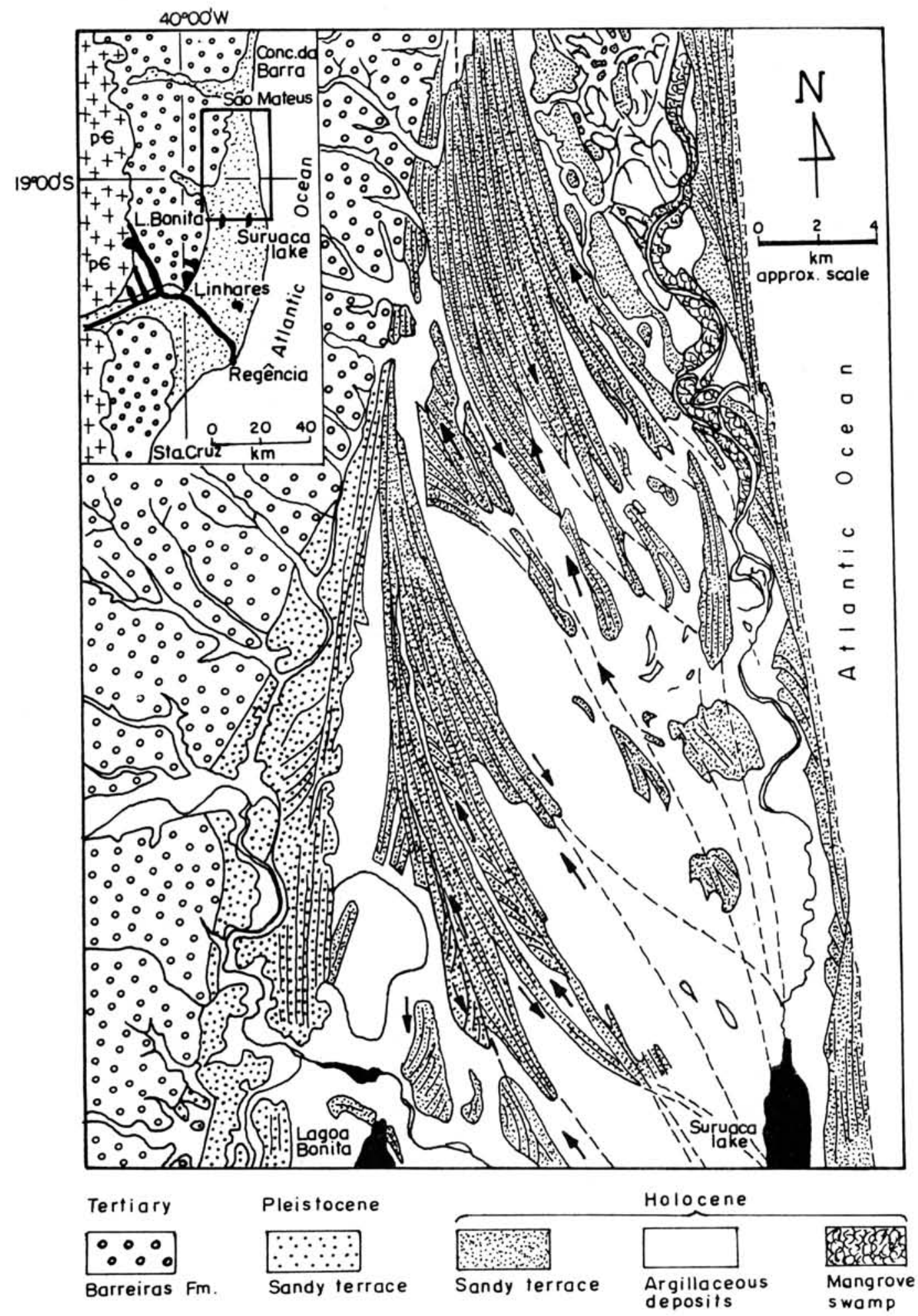

Figure 7 - Doce river coastal plain (State of Espirito Santo) showing littoral drift inversion episodes recognized by the geometry and alignment of beach ridges on sandy plains. 


\section{CONCLUSIONS}

The local upwelling intensity variations in Cabo Frio, recorded in carbonate deposits of a small hypersaline lake, as well as the inversions in the direction of sediment drift, registered in the Doce river coastal plain beach ridges of the last 5,000 years, could be explained by changes in wind regimes over South America. These variations are similar to that produced in 1983 as a consequence of "El Niño" phenomenon along the coast of Equador and Peru. However, "El Niño" has a duration of only about some months and it is not possible to call as paleo "El Niños" because they have been active during some tens or hundreds of years. It seems to be more logical to consider as "El Niño" - like conditions. On the other hand, as the "El Niño" phenomenon is a consequence of austral oscillation, it could be more adequate to assume conditions equivalent to austral oscillations periods.

\section{REFERENCES}

ALARD, P. (1955) Anomalies dans les températures de l'eau de mer observées au Cabo Frio (Brésil) Bulletin d'Information du Comite Central d'Oceanographie et d'Étude des Côtes., 2:58-63.

BOGIN, B. (1982) Climate change and human behaviour on the southwest coast of Ecuador. Central lssues in Anthropology, 4(1):25-50.

DOMINGUEZ, J.M.L; BITTENCOURT, A.C.S.P.; MARTIN, L. (1983) O papel da deriva litorânea de sedimentos arenosos na construção das planícies costeiras dos rios São Francisco (SE/AL), Jequitinhonha (BA), Doce (ES) e Paraf́ba do Sul (RJ). Revista Brasileira de Geociênicas, 13(2):98105.

FARIAS, F.F.; BITTENCOURT, A.C.S.P.; ZANINI JR., A.; DOMINGUEZ, J.M.L (1985) Variações temporais e espaciais na dinâmica de sedimentação da praia de Armação, Salvador (BA). Revista Brasileira de Geociências, 15(1):48-54.

HISARD, P.H. (1988) El Ninõ au secours des anthropologues et des sismologues . Bull Liaison Climat., 21:6-7.

KOUSKY, V.E.; KAGANO, M.T.; CAVALCANTI, I.F.A. (1984) A review of Southern oscillation: oceanicatmospheric circulation changes and related rainfall anomalies. Tellus, 36A:490-504. 
MARTIN, L; FLEXOR, J.M.; KOUSKY, V.F.; CAVALCANTI, I.F.A. (1984) Inversion du sens du transport littoral enregistrées dans les cordons littoraux de la plaine côtière du Rio Doce (Brésil). Possible liaison avec des modifications de la circulation atmosphèrique. Comptes Rendus Hebdomadaires des Seances de l'Academie des Sciences. Ser. II, 298(1):25-27.

MARTIN, L; SUGUIO, K.; FLEXOR, J.M.; DOMINGUEZ, J.M.L; BITTENCOURT, A.C.S.P. (1987) Quaternary evolution of the central part of the Brazilian coast. The role of relative sea-level variation and of shoreline drift. UNESCO Reports in Marine Science (43):97-145.

MARTIN, L; FLEXOR, J.M.; VALENTIN, J.L. (1988) Influence du plénomène océanographique Pacifique sur la côte brésilienne de l'État de Rio de Janeiro. Comptes Rendus Hebdomadaires des Seances de l'Académie des Sciences. Ser. II, (307):1101-1105.

MARTIN, L; DOMINGUEZ, J.M.L; SUGUIO, K. (1987) Consequence of relative sea-level changes during the Quaternary on sandy coastal sedimentation: examples of Brazil. Quaternary of South America and Antarctic Peninsula, 4:119-135.

MOREIRA DA SILVA, P.C. (1973) A ressurgência em Cabo Frio. Publicação. Instituto de Pesquisas da Marinha, (78):1-56.

ORTUEB, L; MACHARÉ, J.; FOURNIER, M.; WOODMAN, P. (1989) Late Holocene beach ridge sequences in northern Peru: did they register the strongest paleo "EI Niños". In: INTERNATIONAL SYMPOSIUM ON GLOBAL CHANGES IN SOUTH AMERICA DURING THE QUATERNARY. Special Publication, 1: Program, Abstracts and general informations. São Paulo, ABEQUA/INQUA, 1989. p.206-209.

SUGUIO, K.; MARTIN, L; BITTENCOURT, A.C.S.P.; DOMINGUEZ, J.M.L; FLEXOR, J.M. (1985) Flutuações do nivel relativo do mar durante o Quaternário superior ao longo do litoral brasileiro e suas implicações na sedimentação costeira. Revista Brasileira de Geociências, 15(4):273-286. 